\title{
PENGARUH GAYA HIDUP DAN EKUITAS MEREK TERHADAP KEPUTUSAN PEMBELIAN HANPHONE MEREK SAMSUNG DI KOTA PALU
}

\author{
Faigah A. Badjamal \\ (Dosen Fakultas Ekonomi Universitas Alkhairaat) \\ Email \\ Faigahbadjamal0165@gmail.com
}

\begin{abstract}
ABSTRAK
Penelitian ini mengungkapkan pengaruh Gaya Hidup dan Ekuitas merek terhadap keputusan pembelian Handphone Samsung. Tujuan yang ingin dicapai dalam penelitian ini untuk mengetahui pengaruh Gaya Hidup dan Ekuitas merek terhadap keputusan pembelian Handphone Samsung. Metode yang digunakan penelitian ini bersifat verifikatif dengan alat bantu kuesioner terhadap 40 responden.

Hasil penelitian ini membuktikan bahwa melihat hubungan antara 2 variabel bebas gaya hidup dan ekuitas merek sebesar 0,499 artinya hubungan variabel bebas (independen) terhadap variabel keputusan pembelian (dependen) adalah hubungan sangat kuat. $\mathrm{R}$ Square atau koefisien determinasi $\left(\mathrm{R}^{2}\right)$ adalah melihat pengaruh antara gaya hidup dan ekuitas merek terhadap keputusan pembellian 0,249 artinya pengaruh variabel bebas (independen) terhadap variabel terikat (dependen) sebesar 24,9\%, sedangkan sisanya 75,1\% pengaruh variabel lain yang tidak diteliti dalam penelitian ini.
\end{abstract}

Kata Kunci: Gaya Hidup, Ekuitas Merek.

\section{LATAR BELAKANG}

Di era globalisasi, persaingan bisnis dalam dunia pemasaran telah berkembang sangat pesat. Hal ini menyebabkan munculnya suatu peluang dan tantangan bisnis yang baru bagi setiap perusahaan yang tentunya akan meningkatkan persaingan terhadap perusahaan sejenis. Oleh sebab itu, setiap perusahaan akan berusaha keras untuk membangun nilai terhadap suatu produk serta membangun merek yang kuat agar bisa memberikan nilai yang positif bagi konsumen yang akan mempengaruhi keputusan konsumen. Menurut (Azis, 2019) Citra merek bagi konsumen merupakan suatu pegangan yang penting dalam sebuah keputusan. Citra merek dapat dianggap sebagai asosiasi yang muncul dalam benak konsumen ketika mengingat suatu merek tertentu. Keputusan pembelian konsumen akan suatu produk dipengaruhi oleh banyak faktor. Oleh karena itu, setiap perusahaan dituntut harus dapat membuat strategi yang tepat agar konsumen membuat keputusan untuk membeli produk yang dihasilkannya tersebut.
Perilaku pembelian (purchase behavior) menurut John A.Horward (2007) merupakan tindakan yang nyata dari pembeli dalam membeli suatu merek tertentu. Konsumen memiliki perilaku yang berbeda-beda ketika akan membeli suatu produk.konsumen akan lebih aktif dalam mencari informasi yang membantu dalam memilih produk yang diinginkan. Sebelum memutuskan untuk membeli,konsumen akan melalui beberapa tahapan mulai pengenalan masalah, pencarian informasi, evaluasi alternative, keputusan pembelian, dan perilaku pasca membeli (Kotler\&Keller, 2007).

Keputusan pembelian konsumen merupakan hal yang sangat penting bagi perusahaan, sebab hal tersebut merupakan tujuan akhir yang ingin dicapai oleh perusahaan. Fenomena tersebut juga terjadi pada industri elektronik, dimana terdapat banyak pesaing yang memasarkan produk sejenis pada segmen yang sama, sehingga perusahaan-perusahaan yang berada pada industri alat-alat elektronik harus dapat mempengaruhi keputusan pembelian konsumen terhadap produk mereka agar dapat 
menguasai pasar sasaran. Salah satu strategi perusahaan agar dapat mempengaruhi keputusan pembelian konsumen yaitu dengan melihat gaya hidup konsumen dan memperkuat merek (brand).

Terdapat banyak faktor yang dapat mempengaruhi perilaku konsumen dalam proses pengambilan keputusan pembelian. Seperti yang dikemukakan oleh Kotler dan Keller (2007), bahwa proses pengambilan keputusan konsumen di pengaruhi oleh banyak faktor baik faktor pemasaran seperti produk, harga, distribusi dan promosi maupun faktor lainnya seperti faktor ekonomi, teknologi, politik, dan budaya. Faktorfaktor tersebut dalam interaksinya dapat mempengaruhi perilaku konsumen baik secara parsial maupun simultan. Menurut Kotler dan Keller (2003), indikator yang dapat di gunakan untuk mengukur keputusan pembelian adalah : pemilihan produk, pemilihan merek, pemilihan dealer, penetapan waktu pembelian, jumlah pembelian, metode pembayaran. Namun dalam penelitian ini hanya menggunakan dua indikator yaitu: penetapan waktu pembelian dan metode pembayaran karena didasarkan pada alasan sesuai dengan objek penelitian beserta karakteristiknya dan jumlah sesuai dengan peneliti mengenai keputusan pembelian handphone Samsung.

Keputusan pembelian konsumen tidak terlepas dari gaya hidup mereka yang ingin membeli produk yang bermanfaat dan mempunyai kualitas yang baik. Keanekaragaman konsumen dalam memenuhi kebutuhannya dipengaruhi oleh karakteristik gaya hidup yang diukur berdasarkan aktivitas dimana seseorang melakukan kegiatan dalam memenuhi kebutuhannya seperti pekerjaan, hobi, belanja, hiburan, olahraga, dan minat seseorang berdasarkan keinginan terhadap produk yang diinginkan, serta pendapat atau pandangan seseorang terhadap produk yang akan dibeli sehingga dapat mempengaruhi perilaku keputusan konsumen. Dalam penelitian Sumarwan, 2004. Menjelaskan bahwa gaya hidup memiliki peran penting dalam keputusan pembelian konsumen termotivasi untuk membeli produk dalam rangka mempertahankan atau mengejar gaya hidup tertentu. Dengan demikian komunitas berperan penting dalam keputusan pembelian karena komunitas digunakan oleh konsumen sebagai dasar dalam evaluasi produk.

Samsung merupakan perusahaan elektronik yang didirikan oleh Lee Byung Chull dan Kang Gary pada 1 Maret 1938 di Daegu, Korea. Samsung pada saat ini juga menjadi salah satu brand terbesar didunia sampai saat ini dengan mengeluarkan Smartphone yang menjadi jawara dalam persaingan bursa pasar gudget.

Era kejayaan Samsung telah lahir pada tahun 1990-an. Bahkan Samsung merupakan salah satu perusahaan yang mampu selamat dari krisis keuangan Asia pada tahun 1997 silam.

Kota Palu merupakan salah satu wilayah yang berkembang pesat akan teknologi dibidang elektronik dimana masyarakat menggunakan handphone sebagai alat komunikasi hal ini menunjukkan bahwa permasalahan yang diangkat oleh penulis salah satunya adalah masyrakat lebih memilih membeli suatu produk sebagai alat komunikasinya karna mengikuti tren atau gaya hidup atau selera yang tinggi dan handphone Samsung sudah menjadi brand yang sangat terkenal di masyarakat khususnya di Kota Palu.

Berbagai uraian tersebut, telah menunjukkan suatu fenomena yang membuat suatu ketertarikan bagi penulis untuk melakukan penelitian dengan judul " Pengaruh Gaya hidup dan Ekuitas merek Terhadap Keputusan Pembelian Handphone Samsung (Studi Pengguna Handphone Samsung di Kota Palu)".

Permasalahan yang diangkat dalam penelitian ini adalah:

1. Apakah gaya hidup dan Ekuitas merek secara serempak berpengaruh signifikan terhadap keputusan pembelian handphone Samsung (pengguna handphone merek Samsung Masyarakat Kota Palu)

2. Apakah gaya hidup berpengaruh signifikan terhadap keputusan pembelian handphone Samsung (pengguna handphone merek Samsung Masyarakat Kota Palu)

3. Apakah ekuitas merek berpengaruh signifikan terhadap keputusan pembelian handphone Samsung (pengguna handphone merek Samsung Masyarakat Kota Palu)

\section{KAJIAN PUSTAKA}

\section{Pemasaran}

Menurut Lupiyaodi (2006 : 34) fasilitas adalah sarana yang digunakan untuk memperlancar dan memudahkan menjalankan fungsi. Adapun yang dapat memudahkan dan melancarkan fungsi ini dapat berupa benda-benda maupun uang. Semakin baik fasilitas yang digunakan dapat meningkatkan kinerja

Menurut (Umar A, 2019) Salah satu konsep yang penting dalam konsep pemasaran modern saat ini adalah konsep marketing mix. Konsep ini 
merupakan salah satu kegiatan atau aspek pemasaran yang sangat menentukan keberhasilan perusahaan dalam usaha untuk mengejar tujuannya yang utama yaitu maximum profit atau laba maksimum. Keberhasilan suatu perusahaan mencapai tujuan perusahaan sangat dipengaruhi oleh kemampuan perusahaan dalam memasarkan produknya. Tujuan perusahaan untuk dapat menjamin kelangsungan hidupnya. Pemasaran dapat didefinisikan sebagai kegiatan yang bersangkutan dengan berpindahnya barang dari produsen pertama ke konsumen terakhir (Sriyadi, 1991).

Kotler (2000), mendefinisikan pemasaran sebagai suatu proses perencanaan dan pelaksanaan pemikiran, penetapan harga, promosi serta penyaluran gagasan, barang dan jasa untuk menciptakan pertukaran yang memenuhi sasaran-sasaran individu dan pemasaran merupakan suatu usaha untuk memuaskan kebutuhan pembeli dan penjual (Swasta,1996).

Menurut American Marketing Association (AMA) (dalam Khotler dan Keller, 2009). Pemasaran adalah fungsi organisasi dan serangkaian proses untuk menciptakan, mengkomunikasikan dan memberikan nilai kepada pelanggan dan untuk mengelolah hubungan pelanggan dengan cara yang menguntungkan organisasi dan pemangku kepentingannya.

\section{Pengertian Manajemen Pemasaran}

Kegiatan pemasaran tidak terlepas dari apa yang dinamakan dengan manajemen pemasaran, dimana seluruh fungsi-fungsi manajemen diaplikasikan kedalam kegiatan pemasaran, agar seluruh kegiatan pemasaran dapat berjalan optimal dan pada akhirnya dapat memberikan hasil yang memuaskan bagi perusahaan.

Menurut Kotler \& Keller (2009) manajemen pemasaran adalah sebagai seni dan ilmu memilih pasar sasaran dan meraih mempertahankan, serta menumbuhkan pelanggan dengan menciptakan, mengantarkan dan mengkomunikasikan nilai pelanggan yang unggul.

\section{Gaya Hidup}

Menurut Kasali (2001) gaya hidup merupakan pola konsumsi yang mencerminkan pilihan seseorang terhadap berbagai hal serta bagaimana menghabiskan waktu dan uangnya. Salamon (2007) mendefinisikan gaya hidup mencerminkan pola konsumsi yang menggambarkan pilihan seseorang bagaimana ia menggunakan waktu dan uang (lifestyle refers to a pattern of consumption reflection a person's choices of how hw or she spend time and money). Sedangkan konsep yang terkait gaya hidup adalah psikografik, dimana psikografik merupakan suatu instrumen untuk mengukur gaya hidup yang memberikan pengukuran kuantitatif. "Psikografik sering dikaitkan sebagai pengukuran AIO (activity, interest,opinion) yang mengacu pada pengukuran kegiatan, minat, dan pendapatan" (Sumarwan, 2002).

Menurut Assael (1992) yang dikutip Sutisna (2002) para peneliti pasar yang menganut pendekatan gaya hidup cenderung mengklasifikasikan konsumen berdasarkan variabel variabel AIO. Salah satu segmentai gaya hidup pada mahasiswa adalah mahasiswa konservatif-trendsetter, yaitu sekelompok mahasiswa dengan karakteristik berpakaian lebih mengikuti mode dibandingkan kebanyakan orang, berpendapat bahwa dirinya adalah orang yang berpendidikan, mengakui bahwa dirinya adalah orang yang suka pamer, ingin dinilai sebagai orang yang mengikuti mode, suka dengan rutinitas hidupnya dengan suka berkelompok atau mengikuti komunitas. Berdasarkan kajian teori tersebut, diperoleh indikator gaya hidup yang mengacu kepada segmentasi mahasiswa konservatif-trendsetter yaitu :

1. Aktivitas adalah orang dengan gaya hidup konservatif-trendsetter senang berkelompok, aktif dalam komunikasi tertentu, suka berbelanja dan berpenampilan baik dengan menggunakan pakaian yang bagus

2. Minat adalah orang dengan gaya hidup konservatif-trendsetter biasanya tertarik dengan mode, pakaian dan pendidikan

3. Opini adalah orang dengan gaya hidup konservatif-trendsetter menganggap berbusana adalah sebuah aktualisasi diri.

\section{Ekuitas Merek}

Terdapat banyak makna dalam konsep ekuitas merek (brand equity), dalam perspektif finansial, ekuitas merek sebagai net present value (NPV) dari aliran kas masa datang yang dihasilkan oleh suatu merek. Dengan kata lain ekuitas merek dihitung berdasarkan nilai inkremental diatas nilai yang diperoleh produk tanpa merek (Tjiptono 2005).

Widjaja, dkk (2007) mendefinisikan ekuitas merek sebagai seperangkat liabilitas 
merek yang berkaitan dengan suatu merek, nama, dan simbolnya, yang menambah atau mengurangi nilai yang diberikan oleh suatu barang dan jasa kepada perusahaan atau pelanggan. Knapp (2001) mendefinisikan ekuitas merek sebagai totalitas dari persepsi merek, mencakup kualitas relatif dari produk barang dan jasa, kinerja keuangan, loyalitas pelanggan, kepuasan dan keseluruhan penghargaan terhadap merek.

\section{Menurut Aaker dalam Darmadi dkk} (2004) ekuitas merek dapat dikelompokkan kedalam 5 kategori :

1. Kesadaran merek

Menunjukkan kesanggupan seorang calon pembeli untuk mengenali atau mengingat kembali bahwa suatu merek merupakan bagian dari kategori produk tertentu.

2. Asosiasi merek

Mencerminkan pencitraan suatu merek terhadap suatu kesan tertentu dalam kaitannya dengan kebiasaan, gaya hidup, manfaat, atribut produk, geografis, harga, pesaing, selebritis dan lain-lain.

3. Persepsi kualitas

Mencerminkan persepsi pelanggan terhadap keseluruhan kualitas/ keunggulan suatu produk atau jasa layanan berkenaan dengan maksud yang diharapkan.

4. Loyalitas merek

Mencerminkan tingkat keterkaitan konsumen dengan suatu merek produk

\section{Keputusan Pembelian}

Menurut (Latoki, 2019) Kemampuan produk untuk memberikan kepuasan pada pemakainya akan menguatkan kedudukan atau posisi produk dalam benak konsumen, sehingga memungkinkan konsumen menjadikan pilihan pertama bilamana akan terjadi pembelian diwaktu yang akan datang. Keputusan pembelian merupakan sebuah tindakan yang dilakukan konsumen untuk membeli suatu produk. Setiap produsen pasti menjalankan berbagai strategi agar konsumen memutuskan untuk memberli produknya. Artikel berikut ini akan membahas tentang pengertian keputusan pembelian dan peranan konsumen dalam keputusan pembelian.

Menurut Kotler dan Amstrong (2011), keputusan pembelian adalah tahap dalam proses pengambilan keputusan pembelian dimana konsumen benar-benar membeli. Pengambilan keputusan merupakan suatu kegiatan individu yang secara langsung terlibat dalam mendapatkan dan mempergunakan barang yang ditawarkan. Menurut Danang Sunyoto (2012), Tahapan dalam keputusan pembelian adalah Sebagai Berikut ;

\section{Pengenalan Masalah}

Masalah timbul dari dalam diri konsumen yang berupa kebutuhan yang digerakkan oleh rangsangan diri dalam diri pembeli atau dari luar. Semua rangsangn yang ada pada diri konsumen menyebabkan suatu masalah.

\section{Pencarian Informasi}

Setelah timbul suatu masalah berupa kebutuhan yang digerakkan oleh rangsangan dari luar, dan adanya dorongan untuk memenuhi kebutuhan tersebut, konsumen akan mencari informasi tentang objek yang bisa memuaskan keinginan. Pencarian informasi tergantung oleh kuat lemahnya kebutuhan, banyaknya informasi yang telah dimiliki maka dapat memberikan penilaian terhapa informasi yang diperolehnya.

\section{Penilaian Alternatif}

Dari informasi yang diperoleh konsumen, digunakan untuk memperoleh gambaran yang lebih jelas mengenai alternatif-alternatif yang dihadapi serta daya tarik masing-masing alternatif.

4. Keputusan Pembeli

Tahap evaluasi berakibat bahwa konsumen membentuk preferensi diantar altenatifalterntif merek barang. Biasanya barang dengan merek yang disukainya adalah barang dengan yang akan dibelinya. Disamping sikap, ada dua faktor yang mempengaruhi nilai seseorang untuk membeli yaitu : Faktor sosial dan Faktor situasi.

\section{Perilaku Setelah Pembelian}

Setelah melakukan pembelian, konsumen akan merasakan kepuasan atau mungkin ketidakpuasan. Ini menarik bagi produsen untuk memerhatikan tindakan konsumen setelah melakukan pembelian. Konsumen dalam memenuhi keinginannya, mempunyai pengharapan agar bisa terpuaskan. Pengharapan konsumen dapat timbul dari pesan-pesan yang diterima dari para penjual, teman, dan sumber lain bahkan perusahaan sendiri.

\section{Hubungan Antara gaya hidup dengan keputusan pembelian}

Menurut Enggel (1995) gaya hidup yang dianut seseorang ikut menentukan pemilihan serta 
keputusan pembelian sebuah produk. Dalam penelitian ini gaya hidup konsumen dimaksudkan pada gaya hidup pengguna Samsung dimana seorang konsumen tidak dapat lepas dari Samsung dalam kegiatan sehari-hari.

Menurut Kartajaya (2011) dalam Marketing to Netizen, "Gaya hidup pengguna Samsung tidak lepas dari gaya hidup sosial masyarakat para pengguna internet. Gaya hidup Netizen mengalami transformasi dengan adanya berbagai tren sosial mulai dari blog, facebook, twitter, dan beragam media social lainnya". Para pengguna internet yang aktivitas sehari-harinya tidak dapat lepas dari dunia maya dan bergantung pada teknologi internet membutuhkan suatu alat atau perantara yang dapat memenuhi kebutuhannya. Para pengguna internet ini mempunyai peran sebagai influencer yang dapat mempengaruhi dan membentuk opini melalui komunitas mereka. Hal inilah yang dimanfaatkan perusahaan handphone Samsung dalam meluncurkan produk Samsung dalam memenuhi kebutuhan konsumen sehingga dapat mengikuti perkembangan zaman.

\section{Hubungan Antara Hubungan Ekuitas merek dengan keputusan pembelian}

Ekuitas merek handphone Samsung dapat menambah dan mengurangi nilai yang diberikan kepada sebuah produk. Sehingga Aset Ekuitas merek (Kesadaran merek, Loyalitas merek, dan asosiasi merek) terhadap handdphone Samsung dapat membantu konsumeen dalam menafsirkan, memproses, dan menyimpan informasi yang terkait dengan produk dan merekk handphone Samsung. Dengan hal tersebut dapat mempengaruhi konsumen dalam mengambil keputusan pembelian handphone Samsung. Rangkuti (2004) menjelaskan apabila konsumen dihadapkan pada pilihan seperti nama merek, harga, serta atribut produk yang lain, ia akan cenderung memilih nama merek terlebih dahulu setelah itu baru memikirkan harga. Dari hasil penelitian tersebut dapat disimpulkan bahwa merek yang disertai variabel Ekuitas Merek yaitu Kesadaran Merek, Kesan Kualitas, Asosiasi Merek, dan Loyalitas Merek sangat berpengaruh terhadap Keputusan Pembelian. Ekuitas Merek menjadi faktor utama dalam penentu keputusan pembelian

Ekuitas merek dapat mempengaruhi rasa percaya diri konsumen dalam pengambilan keputusan pembelian atas dasar pengalaman masa lalu dalam penggunaan atau kedekatan, dan asosiasi dengan berbagai karakteristik merek
(Durianto, dkk, 2004). Semakin kuat ekuitas merek suatu produk, maka semakin kuat pula daya tariknya di mata konsumen untuk mengkonsumsi produk tersebut dan pada akhirnya akan mengarah pada keputusan pembelian produk (Durianto, dkk, 2004).

\section{METODE PENELITIAN Populasi}

Populasi (population atau universe) adalah jumlah dari keseluruhan objek (satuan-satuan atau individu-individu) atau disebut unit analisis yang karakteristiknya hendak diduga (Djarwanto, dkk., 1993). Populasi dalam penelitian ini adalah seluruh konsumen yang membeli handphone samsung (pengguna handphone Samsung Kota Palu Adapun jumlah populasinya tidak dikatahui secara pasti karena tidak memiliki data yang pasti mengenai pengguna handphone Samsung (pengguna handphone Samsung Masyarakat Kota Palu).

\section{Defenisi Operasional Variabel}

Dalam penelitian ini yang merupakan variabel independen yaitu gaya hidup (X1), Ekuitas Merek (X2) serta variabel dependen yaitu keputusan pembelian (Y). Definisi operasional variabel dalam penelitian ini adalah sebagai berikut.

1. Gaya Hidup.

Gaya hidup adalah psikografik, dimana psikografik merupakan suatu instrumen untuk mengukur gaya hidup yang memberikan pengukuran kuantitatif. 'psikografik sering dikaitkan sebagai pengukuran AIO (activity, interest,opinion) yang mengacu pada pengukuran kegiatan, minat, dan pendapatan"(Sumarwan, 2002).

Menurut Assael (1992) yang dikutip Sutisna (2002) para peneliti pasar yang menganut pendekatan gaya hidup cenderung mengklasifikasikan konsumen berdasarkan variabel variabel AIO. Salah satu segmentai gaya hidup pada mahasiswa adalah mahasiswa konservatif-trendsetter, yaitu sekelompok mahasiswa dengan karakteristik berpenampilam lebih mengikuti mode dibandingkan kebanyakan orang, berpendapat bahwa dirinya adalah orang yang berpendidikan, mengakui bahwa dirinya adalah orang yang suka pamer, ingin dinilai sebagai orang yang mengikuti mode, suka 
dengan rutinitas hidupnya dengan suka berkelompok atau mengikuti komunitas. Menurut Prasrtijo dan Lhalauw (2004:68) mengungkapkan AIO adalah :
a. Aktivitas
b. Minat
c. Opini

\section{Ekuitas merek}

Empat elemen ekuitas merek diluar aset aset lainnya dikenal dengan elemen-elemen utama dari ekuitas. Elemen ekuitas merek yang kelima secara langsung akan dipengaruhi oleh kualitas dari empat elemen berikut; (Durianto dkk 2004).

\section{a. Kesadaran merek \\ b. Asosiasi merek \\ c. Persepsi kualitas \\ d. Loyalitas merek}

Mencerminkan tingkat keterkaitan konsumen dengan suatu merek produk. Loyalitas merek ini menjadi ukuran seberapa besar kemungkinan pelanggan akan pindah ke merek lain. Konsumen yang loyal pada umumnya akan melanjutkan pembelian merek tersebut walaupun dihadapkan pada banyak alternatif merek produk pesaing yang menawarkan karakteristik produk yang lebih unggul dipandang dari berbagai sudut atributnya

\section{Keputusan pembelian konsumen}

Keputusan pembelian konsumen merupakan proses yang dilakukan oleh setiap konsumen dalam memperoleh sebuah produk yang pada akhirnya berpengaruh pada keputusan konsumen tersebut untuk bertahan pada suatu merek tertentu.

Menurut Danang Sunyoto (2012), Tahapan dalam keputusan pembelian adalah Sebagai Berikut :

a. Pengenalan Masalah

b. Pencarian informasi

c. Penilaian alternatif

d. Keputusan pembeli

e. Perilaku setelah pembelian

Setelah melakukan pembelian, konsumen akan merasakan kepuasan atau mungkin ketidakpuasan. Ini menarik bagi produsen untuk memerhatikan tindakan konsumen setelah melakukan pembelian.
Konsumen dalam memenuhi keinginannya, mempunyai pengharapan agar bisa terpuaskan. Pengharapan konsumen dapat timbul dari pesan-pesan yang diterima dari para penjual, teman, dan sumber lain bahkan perusahaan sendiri.

\section{Uji Validitas}

Menurut Malholtra dalam Salimun (2007) mengatakan bila koefisien korelasi antar skor suatu indikator dengan skor total seluruh indikator adalah positif dan lebih besar 0,3 ( $\mathrm{r} \geq 0,3)$ maka instrumen tersebut dianggap valid dan jika indikatornya dengan skor total seluruh indikator adalah positif dal lebih kecil $0,3(\mathrm{r} \leq 0,3)$ maka instrumen tersebut dianggap tidak valid. Hasil penelitian untuk uji validitas pada penelitian ini menggunakan 40 sampel dengan memakai program SPSS 21 For Windows Uji Reliabilitas

Pengujian rehabilitas dilakukan dengan mengukur tingkat atau besaran alpha croncach. Suatu koesioner yang baik harus memiliki konsistensi tinggi, dalam arti bahwa kuesioner tersebut akan memberikan hasil yang relatif sama meskipun digunakan secara berulang pada populasi yang sama. Menurut Malholtra dalam Salimun (2002) suatu instrumen atau seluruh indikator dianggap sudah cukup reliabel apabila memiliki alpha concbach lebih besar 0,6 $(\alpha \geq 0,6)$.

Pengujian reliabilitas dilakukan dengan mengukur tingkat atau besaran Alpha Cronbach. Suatu kuesioner yang baik harus memiliki konsistensi yang tinggi dalam arti bahwa kuesioner tersebut akan memberikan hasil yang relatif sama meskipun digunakan secara berulang pada populasi yang sama.

Menurut Malholtra dalam Salimun (2002) suatu instrumen atau seluruh indikator dianggap sudah cukup reliabel apabila memiliki alpha cronbach lebih besar dari 0,6 $(\alpha \geq 0,6)$. Hasil penelitian untuk uji reliabilitas padda penelitian ini menggunakan 40 Sampel dengan memakai program SPSS 21 for windows dan dapat diketahui masing-masing variabel mempunyai alpha sebagaimana yang dilihat pada tabel 3.6 sebagai berikut : 
Tabel 1. Hasil Uji Reliabilitas

\begin{tabular}{|l|l|l|}
\hline \multicolumn{1}{|c|}{ Variabel } & $\begin{array}{c}\text { Alpha } \\
\text { Cronbach }\end{array}$ & Keterangan \\
\hline Gaya Hidup (X1) & .700 & Reliable \\
\hline Ekuitas Merek (X2) & .69 & Reliable \\
\hline $\begin{array}{l}\text { Keputusan } \\
\text { Pembelian (Y) }\end{array}$ & 710 & Reliable \\
\hline
\end{tabular}

\section{Uji Asumsi Klasik}

1. Uji Normalitas.

Alat uji ini digunakan untuk mengetahui apakah dalam sebuah model regresi, nilai residual dari regresi mempunyai distribusi yang normal. Jika distribusi dari nilai-nilai residual tersebut tidak dapat dianggap berdistribusi normal, maka dikatakan ada masalah terhadap asumsi normalitas.

Pengujian ini secara praktis dilakukan lewat output grafik normal probability plot. Dengan menggunakan bantuan program statistik hasil uji normalitas data pada penelitian ini dapat dilihat pada grafik (gambar) di bawah ini:

Gambar 1. Hasil Uji Normalitas

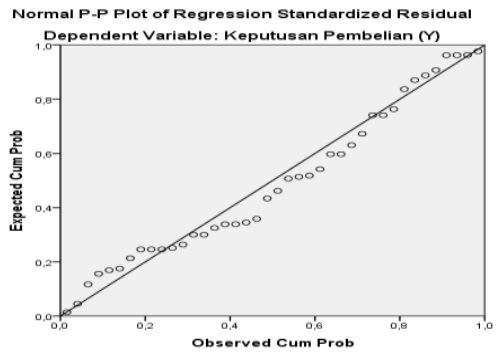

Dari grafik Normal P-Plot terlihat bahwa titik-titik menyebar di sekitar garis diagonal, serta penyebarannya mengikuti garis diagonal maka dapat disimpulkan bahwa model regresi dalam penelitian ini memenuhi asumsi normalitas.

2. Uji Multikolinearitas.

Uji Multikolinieritas dimaksud untuk mengetahui apakah variabel independen tidak saling berkolarasi atau tidak mendapat hubungan yang signifikan antara variabel. Adakalanya korelasi yang tinggi diantara beberapa variabel independen menyebabkan kita tidak dapat untuk mengisolasi pengaruh individual dari variabel bebas terhadap variabel terkait. Bila antara variabel bebas terdapat korelasi secara sempurna atau mendekati sempurna, maka model analisis regresi tidak dapat digunakan.

Suatu variabel menunjukkan gejala multikolinieritas dapad dilihat dari nilai VIF (Variance Inflation Faktor)yang tinggi pada variabel-variabel bebas model regresi. Jika nilai VIF lebih besar dari 10 menunjukkan adanya gejala multikolinieritas dalam model regresi dan jika nilai VIF lebih kecil dari 10 menunjukkan tidak adanya gejala multikolinieritas dalam model regresi.

Suatu variabel menunjukkan gejala multikolinieritas dapat dilihat dari nilai VIF yang tinggi pada variabel-variabel bebas suatu model regresi. Jika nilai VIF lebih besar menunjukkan adanya gejala multikolinieritas dalam model regresi dan jika nilai VIF lebih kecil dari 10 menunjukkan tidak adanya model multikolinieritas dalam model regresi. Hasil pengujian multikolinearitas dengan nilai VIF dapat dilihat ditabel 3.8 yang diperoleh dari hasil olahan data melalui program computer SPSS 21 for windows

Tabel 2. Hasil Uji Multikolinearitas

\begin{tabular}{|c|l|c|l|}
\hline \multirow{2}{*}{ No } & \multirow{2}{*}{ Variabel } & \multicolumn{2}{|c|}{$\begin{array}{c}\text { Collinearity } \\
\text { Statistics }\end{array}$} \\
\cline { 3 - 4 } & & VIF & Tolerance \\
\hline 1 & Gaya Hidup & 0.992 & 1008 \\
\hline 2 & Ekuitas Merek & 0.992 & 1008 \\
\hline
\end{tabular}

3. Uji Heteroskedastisitas.

Heterokedastisitas bertujuan untuk menguji apakah dalam model regresi, terjadi ketidaksamaan varians residual dari satu pengamatan kepengamatan lain. Jika varians tetap maka disebut homoskedastisitas. Dan jika varians berbeda disebut

Heterokedastisitas. Model regresi yang bai adalah tidak terjadi heterokedastisitas. Untuk mendeteksi adanya heterokedastisitas dilakukan dengan melihat ada tidaknya pola tertentu pada grafik, diman sumbu $X$ adalah $Y$ yang telah di prediksi dan sumbu $X$ adalah residual (Y presiksi - Y sesungguhnya) yang telah di-studentized.

Uji heterokedastisitas dilakukan untuk mengetahui apakah dalam semua model regresi, terjadi ketidaksamaan varians dari residual pengamatan kepengamatan lain. Model regresi yang baik adalah model yang 
tidak terjadi heterokedastisitas dapat dilihat pada Gambar 3.9 berikut ini

Gambar 2. Hasil Uji Heteroskedastisitas

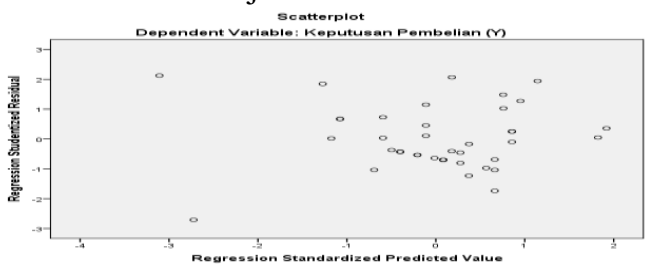

Suatu model regresi dikatakan terdeteksi heterokedastisitas apabila diagram residual tidak membentuk pola tertentuu. Dari hasil diagram scatterplot diatas terlihat bahwa sebaran titik-titik dalam diagram tersebut menyebar dan tidak menunjukkan adanya pola tertentu/pola yang sistematis sehingga dapat dikatakan bahwa tidak terjadi gejala heterokedastisitas.

\section{HASIL DAN PEMBAHASAN \\ Hasil Pengujian Regresi}

Analisis regresi linier berganda digunakan untuk mengetahui seberapa besar pengaruh faktor atau variabel yang digunakan dalam model penelitian yaitu Gaya hidup dan Ekuitas Merek terhadap Keputusan pembelian Hanphone Samsung di Kota Palu. Dalam melakukan pengujian regresi linier berganda, peneliti menggunakan bantuan komputer program SPSS windows versi 21.0. Berdasarkan data yang dikumpulkan dalam penelitian ini serta telah di analisis, diperoleh hasil uji regresi linier berganda pada tabel berikut :

Tabel 2. Hasil Uji Regresi

\begin{tabular}{|c|c|c|c|}
\hline No & Variabel & $\begin{array}{c}\text { Unstandar } \\
\text { dized } \\
\text { Coefficien } \\
\text { ts }\end{array}$ & Sig \\
\hline 1 & Constanta & 29,970 & \\
\hline 2 & Gaya Hidup (X1) &,- 159 & 0.596 \\
\hline 3 & Ekuitas Merek (X2) &, 476 & 0.001 \\
\hline
\end{tabular}

Konstanta $=29,970$

Koefesien Korelasi $(R)=0,499$

Koefesien Determinasi $\left(R^{2}\right)=0,249$

F-Statistik $=6,120$

Sig.F $=0,000$

$a=0,05$
Model regresi yang diperoleh dari tabel diatas adalah:

$\mathrm{Y}=29,970+-, 159 \mathrm{X}_{1}+.476 \mathrm{X}_{2}$

Persamaan diatas menunjukkan, variabel independen yang dianalisis berupa variabel $(\mathrm{X} 1$, $\mathrm{X} 2$ dan $\mathrm{X} 3$ ) memberi pengaruh terhadap variabel independen (Y). Dari persamaan di atas dapat dijelaskan:

1. Nilai constant sebesar 29.970 yang memberikan arti bahwa apabila variabel bebas (Gaya Hidup dan Ekuitas merek ) diasumsikan bernilai nol maka tingkat keputusan pembelian koonsumen pada handphone Samsung akan naik 29,97\%, dimana Variabel lain dianggap konstanta

2. Koefesien Korelasi (R) sebesar 0,499 memberikan arti bahwa variabel yang diamati (gaya hidup) mempunyai hubungan yang kuat dengan variabel terikat (keputusan pembeliaan) sebesar 49,9\%

3. Koefesien Korelasi ( $\mathrm{R}$ square) sebesar 0,249 memberikan arti bahwa $24,9 \%$ variabel keputusan pembelian hanphone mereek Samsung di Kota Palu mampu digambarkaan oleh Variabel Gaya hidup dan Ekuitas merek sedangkan 75,1\% (100-24.9) dipengaruhi oleh variabel indipenden lainnya yang tidak dimasukkaan kedalam penelitian ini

\section{Pengujian Hipotesis Kedua}

Hasil pengujian regresi linear berganda menunjukkan bahwa nilai t-sig variabel gaya hidup sebesar 0.596. Kaidah pengambilan keputusan uji parsial menyatakan bahwa jika nilai $\mathrm{t}$-sig $<\alpha=$ 0,05 , maka secara parsial variabel tersebut tidak berpengaruh keputusan pembelian.

Jika dibandingkan nilai $\mathrm{t}$-sig variable Pelatihan yaitu sebesar 0,596 , berarti nilai $t$-sig lebih besar dari nilai $\alpha=0,05$. Ini membuktikan bahwa secara parsial variabel gaya hidup tidak berpengaruh signifikan terhadap keputusan pembelian handphone samsung. Dengan demikian hipotesis kedua yang diajukan dalam penelitian ini dapat diterima dan terbukti kebenarannya.

\section{Pengujian Hipotesis Ketiga}

Hasil pengujian regresi linier berganda menunjukkan bahwa nilai $\mathrm{t}$-sig variabel ekuitas mereksebesar 0.001. Kaidah pengambilan keputusan uji parsial menyatakan bahwa jika nilai $\mathrm{t}$-sig $<\alpha=0,05$, maka secara parsial variabel ekuitas merek tersebut berpengaruh keputusan pembelian.

Jika dibandingkan nilai $\mathrm{t}_{\text {-sig }}$ variabel ekuitas merek yaitu sebesar 0,001 , berarti nilai $t$-sig lebih 
kecil dari nilai $\alpha=0,05$. Ini membuktikan bahwa secara parsial variabel ekuitas merek berpengaruh signifikan terhadap keputusan pembelian.

\section{Pembahasan \\ Pengaruh Gaya hidup dan Ekuitas merek terhadap keputusan pembelian}

Hasil pembuktian hipotesis dalam penelitian ini pengaruh gaya hidup dan ekuitas merek terhadap keputusan pembelian handphone samsung masyarakat Kota Palu, memberikan pembuktian bahwa kedua variabel independen yaitu gaya hidup dan ekuitas merek berpengaruh signifikan terhadap keputusan pembelian handphone samsung. Dengan demikian dinyatakan bahwa hipotesis mengenai pengaruh gaya hidup dan ekuitas merek terhadap keputusan pembelian handphone samsung di Kota Palu.

Berdasarkan hasil analisis deskriptif Gaya hidup (X1) mempunyai rata-rata 4.19 dan Ekuitas Merek (X2) mempunyai rata-rata 3.96 atau berada pada kategori baik, gaya hidup dan ekuiitas merek secara serempak berpengaruh positif dan signifikan terhadap keputusan pembelian. Hal ini dikarenakan gaya hidup dan ekuitas merek merupakan salah satu faktor yang dapat mempengaruhi seseorang dalam mengambil keputusan dalam membeli suatu produk

Hasil penelitian yang mendukung penelitian ini adalah penelitian yang dilakukan oleh Hardhiani Dian Fathony R.Sugeng Basuki (2017) Administrasi Niaga, Politeknik Negeri Malang "Pengaruh Gaya hidup dan Ekuitas merek terhadap keputusan pembelian IPHONE". Secara simultan gaya hidup dan ekuitas merek berpengaruh positif dan signifikan terhadap keputusan pembelian Iphone dikalangan mahasiswa prodi DIV manajemen pemasaran jurusan administrasi Niaga politeknik negri malang.

\section{Pengaruh Gaya hidup terhadap keputusan pembelian}

Berdasarkan hasil analisis deskriptif Gaya hidup (X1) mempunyai rata-rata skor jawaban responden sebesar 4.19 atau berada pada kategori baik, Namun tidak berpengaruh signifikan terhadap keputusan pembelian handphone di Kota Palu karna dipengaruhi oleh faktor-faktor diluar penelitian yang tidak sempat diteliti Menurut Kasali (2001) gaya hidup merupakan pola konsumsi yang mencerminkan pilihan seseorang terhadap berbagai hal serta bagaimana menghabiskan waktu dan uangnya
Hasil penelitian yang mendukung penelitian ini adalah penelitian yang dilakukan oleh, Hesti Mayasari (2012) yang berjudul Analisis perilaku pembelian ponsel cerdas (smartphone) Antara kebutuhan dan gaya hidup konsumen di kota padang. Hasil pengujian hipotesis dalam penelitian ini ditemukan bahwa gaya hidup tidak berpengaruh signifikan terhadap keputusan konsumen dalam membeli smartphone di kota padang. Didalam tahapan pengujian hipotesis diperoleh nilai koefesien regresi bertanda positif sebesar 0,001. Temuan tersebut diperkuat dengan nilai signifikan sebesar $0.779>0,05$. Keputusannya adalah Ho diterima dan Ha ditolak sehingga dapat disimpulkan bahwa gaya hidup tidak berpengaruh signifikan terhadap keputusan pembelian konsumen pada ponsel berkategori smartphone.

Hasil penelitian yang mendukung penelitian ini adalah penelitian yang dilakukan oleh, Siti Fatimah Fakultas psikologi, Universitas 17 Agustus 1945 Samarinda, pengaruh gaya hidup dan konsep diri terhadap pengambilan keputusan konsumen dalam memilih coffeeshop di samarinda. Hasil uji hipotesis menggunakan analisis regresi model penuh dengan hasil $\mathrm{F}=0,268, R^{2}=0,0005$, dan $\mathrm{p}=0,766$. Untuk hasil analisis model bertahap didapatkan hasil beta $=$ $0,019, \mathrm{t}=-0,129$, dan $\mathrm{p}=0,897$ untuk konsep diri terhadap penggambilan keputusan konsumen dan gaya hidup terhadap pengambilan keputusan konsumen dengan hasil beta $=-0,059, \mathrm{t}=-0,402$, dan $p=0,698$. Dapat disimpulkan bahwa tidak terdapat hubunggan yang signifikan antara gaya hidup dan konsep diri terhadap pengambilan keputusan konsumen tersebtu dalam memilih coffeeshop sebagai salah satu alternatif tempat yang dapat dikunjung.

Penelitian serupa pun terlihat pada penelitian Raeysa Permata Kasih (2012) yang berjudul Analisis Faktor-faktor yang mempengaruhi keputusan konsumen dalam membeli produk merek Value Plus di Matahari Hypermart Pekanbaru.Dalam penelitiannya menyatakan factor sosial yang berupa : kelompok referensi, pengaruh keluarga, pengaruh teman, peran dan status adalah yang paling dominan pengaruhnya terhadap pengambilan keputusan konsumen. Dengan demikian Variabel factor social berpengaruh terhadap keputusan konsumen dalam pembelian produk merek Value Plus di Matahari Hypermart Pekanbaru sedangkan Faktor pribadi yang berupa: usia, pekerjaan, pendapatan, gaya 
hidup, kepribadian, dan konsep diri tidak berpengaruh

Pengaruh Ekuitas merek terhadap keputusan pembelian

Berdasarkan hasil analisis deskriptif Ekuitas merek (X2) mempunyai rata-rata 3.96 atau berada pada kategori baik, hal ini menunjukkan bahwa Ekuitas merek berpengaruh terhadap keputusan pembelian handphone samsung di Kota Palu yang dinilai berdasarkan persepsi responden. Knapp (2001) mendefinisikan ekuitas merek sebagai totalitas dari persepsi merek, mencakup kualitas relatif dari produk barang dan jasa, kinerja keuangan, loyalitas pelanggan, kepuasan dan keseluruhan penghargaan terhadap merek. Hal tersebut dibuktikan dengan penelitian berpengaruh positif dan signifikan, sehingga hipotesis yang diajukan dapat diterimah. Atas dasar ini dapat diketahui bahwa keputusan pembelian dapat diukur dengan melihat Ekuitas merek, hipotesis yang diajukan diterima.

Hasil penelitian yang mendukung penelitian ini adalah penelitian yang dilakukan oleh Risa Amelia (2016) Prodi Manajemen, Sekolah Tinggi Ilmu Ekonomi Perbanas Surabaya, dengan judul penelitian "pengaruh ekuitas merek dan gaya hidup terhadap keputusan pembelian smartphone huwawei" hal ini disebabkan karena memiliki nilai $R^{2}=0,040$.

\section{KESIMPULAN}

\section{Kesimpulan}

Berdasarkan hasil pembahasan dan hasil olahan data pada penelitian ini, maka kesimpulan yang dapat ditarik adalah sebagai berikut:

1. Gaya hidup dan ekuitas merek secara serempak berpengaruh signifikan terhadap variabel keputusan pembelian handphone merek Samsung (pengguna handphone Samsung di Kota Palu) hopotesis pertama terbukti.

2. Gaya hidup tidak berpengaruh signifikan terhadap keputusan pembelian handphone samsung (pengguna Handphone Samsung di Kota Palu) hipotesis kedua tidak terbukti.

3. Ekuitas merek berpengaruh signifikan terhadap keputusan pembelian handphone Samsung (pengguna handphone Samsung di Kota Palu) hipotesis ketiga terbukti.
Saran

Adapun saran-saran yang dapat diajukan dalam penelitian ini dengan melihat hasil pembahasan penelitian adalah sebagai berikut:

1. Kepada pihak perusahaan dalam hal ini adalah Samsung, harus terus mengontrol dan mengevaluasi variabel-variabel yang terbukti memberikan pengaruh yang signifikan terhadap keputusan pembelian handphone merek Samsung (pengguna handphone Samsung di Kota Palu) agar terjadi peningkatan yang baik dari segi produktivitas dan efektivitas perusahaan maupun dari segi keuntungan perusahaan.

2. Untuk penelitian selanjutnya, diharapkan untuk mencari, menambakan, atau bahkan mengkombinasi variabel-variabel pembentuk keputusan pembelian khusunya handphone merek Samsung (pengguna handphone Samsung di Kota Palu). Pada umumnya, agar hasil penelitiannya memberikan kontribusi yang bermakna pada pihak-pihak yang berkepentingan.

\section{DAFTAR PUSTAKA}

Assauri, sofjan, 2010.Manajemen Pemasaran, Cetakan ke 10, PT. Raja grafindo parsada Jakarta

Azis, A. (2019). Pengaruh Citra Merek Dan Kepuasan Konsumen Terhadap Loyalitas Konsumen Sim Card Telkomsel (Studi Pada Pengguna Sim Card Telkomsel Di Ampana Kota). Jurnal Ekonomi Trend, 7(1), 71-82. Https://Doi.Org/10.31970/Trend.V7i1.174

Azwar, saifudin 2003. Validitas dan reabilitas. Edisi kesatu, pustak pelajar.Yokyakarta

Danang Sunioto, 2002. Konsep dasar riset pemasaran dan perilaku konsumen. Jakarta : CAPS

Diyah Amalia, R.abdul Fattah, Sutopo 2017, pengaruh citra merek, ekuitas merek dan gaya hidup terhadap keputusan pembelian Samsung galaxy S series di Surabaya

Durianto, Darmadi \& sugiarto, Toni sitinjak 2004 , Strategi menaklikkan pasar, PT. Gramedia PustakaUtama

Hardhiani Dian Fathony R.Sugeng Basuki (2017) Pengaruh Gaya hidup dan Ekuitas merek terhadap keputusan pembelian IPHONE.

Kotler, Philip \& Amstrong, 2008, Prinsip-prinsip pemasaran, Edisi keduabelas, Jilid 1, penerbit Erlangga, Jakarta. 
Khotler, Philip \& Keller, Kevin, 2009, Manajemen pemasaran, Edisi Ketiga belas jilid1,PenerbitErlangga,Jakarta

Latoki, L. (2019). Pengaruh Kepuasan Konsumen Terhadap Loyalitas Merek Kartu Prabayar Im3 Pada Pegawai Kantor Gubernur Sulawesi Tengah. Jurnal Ekonomi Trend, 7(1), $1-11$. Https://Doi.Org/10.31970/Trend.V7i1.169

Malholtra, N, 2005 ,Metode penelitian, PT Gramedia Pustaka, Utama, Jakarta

Mulyanto, Edy., 2011. Analisis pengaruh kualitas Pelayanan Terhadap Kepuasan Pelanggan Pada Bengkel Ajisaka Motor Kudus.Skripsi.Semarang:Undip

Prasetijo, R. dan j. j. O. lhalaauw. 2004. Perilaku konsumen. Andi offset. Yogyakarta.

Rangkuti, Fredy, 2009. The Power Of Brand. Pt Gramedia Pustaka Utama

Risa Amelia, 2016. Pengaruh ekuitas merek dan gaya hidup terhadap keputusan pembelian smartphone huwawei.

Solimun, (2002). Structural Equation modeling LISREL dan Amos, Fakultas MIPA Universitas Braawijaya, Malang.

Solimun, (2007). Memahami metode analisis kuantitatif mutakhir. Lokakarya statistic mutakhir di universitas Kristen petra, Surabaya.

Setiadi j, Nugroho. 2003 perilaku konsumen :prenada media Jakarta.

Sugiyono, 2005, Metode penelitian, Bisnis : Penerbit Alfabeta, Bandung.

Supranto dan limakrisna, (2011). Perilaku konsumen dan strategi pemasaran "untuk memenangkan persaingan bisnis". Edisi dua. Jakarta : Penerbit Mitra Wacana Media.

Sutisna (2002). Perilaku konsumen dan komunikasi pemasaran. Bandung:Rosda.

Tatik suriyani, (2013). Perilaku konsumen di era interen " implikasinya pada strategi pemasaran”. Edisi pertama. Yokyakarta : Graha Ilmu.

Umar A, M. (2019). Strategi Pemasaran Dalam Upaya Peningkatkan Volume Penjualan Perusahaan Comforta Palu. Jurnal Ekonomi Trend, 7(1), 27-40. Https://Doi.Org/10.31970/Trend.V7i1.171

Umar, Husein. (2005). Metode penelitian Skripsi dan Tesis Bisnis Edisi Baru. Jakarta :PT. Raja Grafindo Persada. 